Віталій Чорний, доктор філософських наук, професор, Національний університет оборони України імені Івана Черняховського

ORCID ID 0000-0003-0342-1188

\title{
НОВІ СОЦІАЛЬНІ МЕДІА ТА СОЦІАЛЬНІ МЕРЕЖІ В ОСВІТНЬОМУ ПРОЦЕСІ
}

\begin{abstract}
Метою статті є дослідження сутності, тенези та можливостей нових соціальних медіа та соціальних мереж в сучасному освітньому процесі. Для иього застосовувалися загальнонаукові та спеціальні методи дослідження. 3'ясовано, щңо освітні соиіальні мережі поєднують слухачів, курсантів, студентів і орієнтовані на взаємодію з метою надання допомоги в реалізачії академічних проектів, проведення наукових досліджень або взаємодії з науково-педагогічними прачівниками. У статті уточнено зміст окремих понять, набули подальшого розвитку погляди щодо їхнього застосування в освітньому процесі. Сучасні війни та прагнення України вступити до НАТО висувають нові вимоги до освітнього проиесу в Збройних Силах Украӥни. Зазначене потребує подальших наукових досліджень нових Інтернет-технологій, 3 метою модернізачії військової освіти, наближення українського війська до стандартів Північноатлантичного альянсу.
\end{abstract}

Ключові слова: нові сочіальні медіа; сочіальні мережі; військова освіта; комунікативний процес; Інтернет; наџіональна безпека; НАТО.

Постановка проблеми. Сучасне інтерактивне суспільство характеризується постійним збільшенням та глобалізацією комунікацій, кількість та якість яких безперервно зростають. Збільшення комунікацій відкриває нові можливості, які звільняють людей від певних обмежень, систем соціального контролю та примусу, створюють нові засади особистої репрезентації. Під час зазначеного процесу особливої популярності набувають нові соціальні медіа i, зокрема, соціальні мережі. Проникнення соціальних медіа та соціальних мереж до сучасного соціуму відбувається настільки швидкими темпами, що практика та наслідки використання нових засобів комунікації залишаються недостатньо вивченими [1]. Не оминули зазначені процеси й військової освіти. Зокрема в Національному університеті оборони України імені Івана Черняховського активно впроваджуються інноваційні форми освіти - дистанційне навчання, проведення КШН 3 використанням автоматизованих систем управління тощо. Як відомо, дистанційне навчання - це сукупність сучасних технологій, що забезпечують доставку інформації в інтерактивному режимі за допомогою використання інформаційно-комунікаційних технологій. Основними принципами дистанційного навчання $€$ інтерактивна взаємодія під час роботи, надання слухачам можливості самостійного освоєння навчального матеріалу, а також консультативний супровід під час дослідницької діяльності.

Аналіз останніх досліджень і публікацій. Оскільки зазначена проблема виникла фактично в останнє десятиліття поточного століття, іï дослідження ще тільки розпочинається. Хоча, заради справедливості, необхідно 
відзначити, що, на сьогодні, з'явилося чимало публікацій, які розкривають сутність, генезу і можливості нових соціальних медіа та соціальних мереж [1-9]. Проте, як свідчить проведений аналіз, серед науковців і практиків бракує розуміння глибинної сутності зазначених соціальних явищ, тому нерідко спостерігається підміна засадничих понять. Водночас, активізація спілкування за допомогою електронних інформаційних технологій у сучасному суспільстві набуває такої щільності та інтенсивності, що дослідники не встигають за практикою впровадження нових комунікативних технологій. Відтак, зміст поняття «соціальна мережа» має декілька значень, які потребують подальшого уточнення.

Зважаючи на вищезазначене метою статті $є$ дослідження сутності, генези та можливостей нових соціальних медіа в сучасному освітньому процесі і, зокрема, в модернізації військової освіти України.

Методи дослідження. Застосування загальнонаукових та спеціальних методів при вивченні нових соціальних медіа та соціальних мереж зумовлене специфікою цього складного соціального явища, функціонування та генеза якого детерміновані різноманітними суспільними умовами.

Виклад основного матеріалу. Поняття «нових соціальних медіа» 3'явилося порівняно недавно у зв'язку 3 виникненням низки нових технологій (RSS, блоги) та інтернет-ресурсів (онлайнові соціальні мережі, відеохостинги). Коло цих явищ поєднує те, що усі вони, порівняно 3 технологіями попереднього покоління, коли Інтернет складався переважно зі статичних сторінок, полегшують обмін інформацією між користувачами.

Для визначення хронологічних меж, у яких актуалізувалося поняття «нові соціальні медіа», необхідно окреслити ключові дати в історії їхнього створення. Як відомо, 90-і pp. XX ст. характеризувалися пануванням культури статичних веб-сторінок. У ці роки з'явилися форуми, на яких користувачі могли створювати свої теми і відповідати на дописи інших людей, а також перші блоги.

Виникнення блогів Й. Бенклер пов'язує 3 появою програмного забезпечення, яке дало можливість змінювати веб-сторінки за допомогою простого та доступного інтерфейсу: «Технічно блоги є частиною ширшої категорії інновацій, які зробили мережу «придатною для листування» ('writable' Web)» [2]. У 1998 р. відбувся запуск сервісу онлайн-щоденників (блогів) Open Diary. У цій ранній формі онлайнової соціальної мережі була створена можливість коментувати записи (пости). У 1999 р. виник блогcepвic LiveJournal. У 2001 р. відбувся запуск багатомовного довідкового pecypcy Wikipedia, який дав змогу користувачам писати та редагувати статті. У 2003 р. була запущена онлайнова соціальна мережа MySpace, на якій існує можливість створення співтовариств за інтересами, персональних профілів, ведення блогів, розміщення фото-, відео- та музичного контенту. У 2004 р. користувачів почала обслуговувати онлайнова соціальна мережа Facebook, яка нині нараховує понад 400 млн абонентів в усьому світі [2]. У 2005 р. був запущений відеохостинг YouTube, який дав змогу користувачам 
завантажувати та дивитися відео безпосередньо зі свого сайту або вставляти відео безпосередньо в тіло веб-сторінки. У 2006 р. відбулося заснування сервісу мікроблогінгу Twitter. Його характерною рисою є обмеження розміру запису 140 символами - формат, що зробив Twitter популярним серед користувачів і зручним для моніторингу та аналізу.

Такий бурхливий розвиток нових засобів комунікації не міг залишитися осторонь теоретиків та практиків. Зокрема, П. Гіллен у своїй праці «Нові агенти впливу» визначає соціальні медіа як багатозначний термін, що поєднує різні онлайн технології в Інтернеті, які надають можливість користувачам спілкуватися та взаємодіяти між собою. Характерною рисою усіх соціальних медіа, на його думку, $\epsilon$ те, що в ролі творців контенту задіяні самі користувачі [3].

Американський журналіст П. Дойль пропонує таке визначення соціальних медіа: це різноманітні онлайн технології, які дають можливість користувачам легко спілкуватися за допомогою Інтернету, ділитися інформацією та ресурсами тощо. Англійський PR-фахівець C. Блек характеризує соціальні медіа як сукупність онлайн технологій та практик, які дають можливість користувачам обмінюватися своїми думками, враженнями та перспективними поглядами. Він стверджує, що соціальні медіа забезпечують комунікацію зацікавлених осіб, що сприяє зміцненню відносин між усіма учасниками процесу [2].

Отже, узагальнення вищенаведених та існуючих у науковій думці та практиці сучасних масових комунікацій уявлень, підходів, поглядів і концепцій дає змогу запропонувати таке визначення зазначеного феномену: нові соціальні медіа - це інтерактивні цифрові способи доставки інформації (повідомлень), засоби комунікації, у яких головним комунікативним джерелом $€$ Інтернет.

Виходячи 3 наведеної дефініції, до нових соціальних медіа 3 повним правом можна віднести: соціальні мережі, блоги, подкасти, web-сайти, інтернет-форуми, Wiki, відеохостинги, онлайнові та мобільні продукти. Крім того, до них належать ще й такі інтерактивні майданчики для спілкування i обміну контентом між користувачами, як форуми, фотохостинги та інші творчі платформи [4].

Що ж до самого поняття «соціальні медіа» (англ. Social media), то на сьогодні його усталеної дефініції теж не існує. Переважно воно вживається в середовищі Інтернет-професіоналів. Найчастіше поняття «соціальні медіа» визначають і як технології, і як різновид Інтернет-сайтів. На практиці технології тісно пов'язані з віртуальними просторами, які функціонують 3 їхньою допомогою. Найпопулярніші сайти, які зазвичай належать до категорії соціальних медіа (Facebook, Twitter, LiveJournal, Wikipedia, YouTube та ін.), мають свій інтерфейс та працюють на засадах певного набору технологій, які роблять цей сайт унікальним засобом комунікації.

В Україні як вид мас-медіа соціальні медіа визначають як низку онлайнових технологій на принципах Web 2.0, завдяки яким споживачі контенту 
через свої дописи стають його співавторами i можуть взаємодіяти, співпрацювати, спілкуватися, ділитися інформацією або брати участь у будьякій іншій соціальній активності практично з усіма користувачами певного сервісу. Як вважає Ю. Половинчак, соціальні медіа охоплюють різні сервіси: соціальні мережі, призначені для забезпечення горизонтального спілкування зацікавлених у ньому користувачів, на зразок Facebook; блогосферу як сукупність блогів - веб-сторінок із датованими записами, що періодично оновлюються і спільноту блогерів, які читають та коментують, посилаються один на одного, що приводить до створення нової субкультури; мікроблогінг як засіб оперативного спілкування, гібридну форму медіа, що поєднує властивості служби миттєвих повідомлень, блогів, електронної пошти та соціальних мереж; відеохостинги, користувачі яких можуть додавати, проглядати та коментувати відеозаписи та інші сервіси мережі [5].

Як свідчить історична практика, коло явищ, охоплених поняттям «соціальні медіа», перетинається 3 іншими поняттями, в тому числі й 3 поняттям «соціальні мережі». Відтак, існує необхідність чіткого розмежування їхнього значення. Так, «соціальні медіа» не $є$ синонімом поняття «нові медіа» або «соціальні мережі». Термін «нові медіа» 3'явився для опису засобів масової комунікації, які виникли під впливом поширення цифрових комп'ютерних технологій у 80-ті рр. ХX ст. Вони, зокрема, охоплюють Інтернет, комп'ютерні ігри, супутникове телебачення. Нові технології значно вплинули й на традиційні мас-медіа (наприклад, використання фото- і текстових редакторів під час підготовки матеріалу до газет). Соціальні медіа є частиною «нових медіа» і складають особливий сегмент Інтернету, наділений перерахованими вище властивостями.

Сучасні комунікаційні технології дають змогу створювати соціальні спільноти (Інтернет-ком'юніті) 3 практично будь-якими заданими характеристиками - освітніми, професійними, віковими. Вони формуються на тлі акселерації соціального часу та посилення динаміки комунікаційних форм під час суспільного відтворення. При цьому стійкі відносини поступаються місцем постійним змінам, а суспільство стає схожим на рефлексивні та комунікативні спільноти.

На сучасному етапі активізація спілкування у суспільстві за допомогою електронних інформаційних технологій набуває такої щільності та інтенсивності, що дослідники не встигають за практикою впровадження нових комунікативних технологій. Відтак, зміст поняття «соціальна мережа» має декілька значень, які потребують подальшого уточнення. У широкому значенні соціальну мережу розглядають як структуру, що складається 3 вузлових елементів та зв'язків між ними, так званої соціальної павутини. 3 технологічного погляду соціальна мережа - це інтерактивний веб-сайт 3 великою кількістю користувачів, контент якого наповнюється самими учасниками.

Сайт $є$ автоматизованим соціальним середовищем, яке дає змогу спілкуватися групі користувачів, об'єднаних загальним інтересом. 
Теоретично соціальною мережею можна вважати будь-яку онлайнову спільноту. Соціальна мережа утворюється користувачами тематичного співтовариства, створеного на будь якому сервісі блогів. Багато професійних співтовариств перетворилися на інструмент пошуку людей та пошуку роботи.

Отже, головною функцією соціальних мереж $є$ об'єднання людей 3 подібними інтересами в одне співтовариство або групу. Появі різноманітних соціальних сервісів, а саме форумів, блогів, соціальних мереж сприяв розвиток Інтернет-технологій Web 2.0 [6].

До обігу термін Web 2.0 запровадило видавництво O'Reilly Media, яке спеціалізується на інформаційних технологіях. Це сталося у 2004 р. 3 того часу сфера Web 2.0 розширилася, витісняючи традиційні Web-cервіси, які отримали назву Web 1.0. Web 2.0 - це комплексний підхід до організації, реалізації та підтримання Web-pесурсів. У Web 2.0 існують беззаперечні переваги. У мережевих сервісах Web 1.0 користувач був пасивним споживачем послуг. Підхід, побудований на засадах концепції Web 2.0, акцентує увагу на активнішій діяльності користувачів, орієнтованій на участь у створенні контенту ресурсу. Під час розвитку сервісу враховуються досвід та думки користувачів зазначеного сервісу. Це робить Web 2.0 ресурси більш інтерактивними, даючи користувачам свободу самовираження.

Перші соціальні мережі з'явилися в середині 90-х pp. XX ст. і надавали користувачам початкові можливості для спілкування (eGroups/OneList, ICQ, Evite). Такі мережеві сервіси, зазвичай, не розглядаються як соціальні мережі, але вони є тими підвалинами, на яких надалі розвивалися онлайн можливості спілкування та взаємодії користувачів. Сервіси, подібні до Friendster, Tribe, Orkut, LinkedIn, Spoke, дали змогу створювати соціальні мережі для відпочинку та роботи. Іншими словами, тогочасні творці соціальних мереж працювали скоріше заради самих мереж та їхнього розвитку, аніж заради використання можливостей, які надають ці мережі.

Офіційним початком буму соціальних мереж вважаються 2003-2004 pp., коли були запушені MySpace та Facebook, найпопулярнішим 3 яких став останній. Не менш широковідомим є сервіс мікроблогів Twitter. У 2007 p. американські дослідники сформулювали основні риси справжньої соціальної мережі, які зводяться до того, що користувачі можуть конструювати публічний або напівпублічний профіль, зазначивши список користувачів, 3 якими хочуть налагодити зв'язок та переглядати і передавати свій список контактів та списки інших користувачів системи.

Прагматичний американський підхід щодо розвитку соціальних мереж грунтувався виключно на задоволенні актуальних соціальних потреб. Серед цих потреб здебільшого актуалізувалася потреба керівництва контактами, кількість яких зростала 3 розширенням кількості користувачів Інтернету. Саме тому американська Інтернет-компанія Ріахо на початку XXI ст. розробила сервіс керівництва контактами, який пізніше гармонійно увійшов і до Facebook. 
Реалізація ще одного важливого суспільного запиту у Сполучених Штатах була пов'язана зі сферою бізнесу. У 2003 р. з'явився Linkedin перша соціальна мережа для ділових людей. Розвиток технологій керівництва контактами призвів до розробки технологій, за допомогою яких користувачі могли об'єднуватися у співтовариства довкола спільного інтересу. Відтак, компанія Tribe запатентувала соціальну мережу, яка оперує базою даних, що дає можливість створювати особистий акаунт і запрошує інших до реєстрації за допомогою електронних листів. Якщо інша особа приймає запрошення і підтверджує дружбу, сервіс створює двосторонній комунікаційний ланцюг.

Виділяють різні види соціальних мереж. Наприклад, публічні (3 відкритим доступом для усіх бажаючих) або закриті, лише для співробітників певної компанії, корпорації, де працівники обговорюють власні проекти та розміщують конфіденційну інформацію. Однією 3 характерних рис соціальних мереж є система «друзів» та «груп». Соціальні мережі також поділяють за спрямованістю: для розваг та відпочинку (загального характеру), для пошуку роботи, професійного зростання, наукового спрямування тощо. Соціальні мережі вивчаються за різними аспектами, наприклад, деякі дослідження розглядають використання соціальних мереж 3 урахуванням таких чинників, як частота відвідування тощо.

Таким чином, соціальні мережі спрямовані на побудову в Інтернеті співтовариств осіб зі схожими інтересами або напрямом діяльності. Зв'язок здійснюється за допомогою внутрішньої пошти або миттєвого обміну повідомленнями. Також існують соціальні мережі для пошуку не тільки людей за інтересами, а й самих об'єктів цих інтересів: сайтів, музики, фільмів тощо. На сайті мережі можна відобразити інформацію про себе (дату народження, рівень освіти, улюблені заняття тощо), за якою акаунт користувача зможуть знайти інші учасники.

Соціальні мережі можна класифікувати за різними категоріями, вони поєднують людей за певними ознаками і відрізняються за внутрішніми правилами співтовариства. Серед ознак соціальних мереж виділяють такі: членські внески, географічні фільтри, використання загальної інформаційної бази, демографічні ознаки, послуги (продукти), які пропонуються в межах співтовариства, загальна маркетингова мета тощо.

Важливою особливістю соціальних мереж $є$ те, що це певне закрите середовище, інформацію в якому можуть отримувати лише його учасники $\mathrm{i}$ лише 3 дозволу іiі власника. Уся інформація, що міститься в соціальних мережах, не проіндексована пошуковими системами, тому соціальні мережі швидше за все $є$ своєрідним Інтернет-сервісом з відповідним інтерфейсом, i при цьому вони не $є$ частиною World Wide Web. Вочевидь основним об'єктом у соціальній мережі є все-таки людина, аніж розміщена там інформація.

Універсальні соціальні мережі не зосереджуються на одній темі або ніші. Головною темою для них $є$ інструмент для пошуку нових контактів, а також для того, щоб залишатися на зв'язку 3 друзями, колегами та 
партнерами. Універсальні соціальні мережі надають можливість користувачам об'єднуватися в групи, які мають спільні інтереси [6].

Інформаційні соціальні мережі - це співтовариство осіб, які шукають вирішення повсякденних проблем. Це ключовий сегмент для маркетологів. Такі ресурси нерідко бувають пов'язані з конкретними підприємствами та компаніями, які зацікавлені в нових каналах просування своїх товарів i послуг. Крім того, в соціальних мережах подається багато інформації у вигляді порад, написаних професіоналами та експертами.

Освітні соціальні мережі поєднують слухачів, курсантів, студентів і орієнтовані на взаємодію з метою надання допомоги в реалізації академічних проектів, проведення наукових досліджень або взаємодії 3 науковопедагогічними працівниками.

Дослідницькі соціальні мережі орієнтуються на академічну аудиторію (наукових працівників, докторантів, ад’юнктів, аспірантів). Такі мережі дають змогу академічним дослідникам займатися спільними науковими розробками.

Соціальні мережі, які спеціалізуються на хобі, є неофіційними і мають змішані групи користувачів. Сдина мета цих груп - обмін інформацією та враженнями за спільними інтересами.

Соціальні мережі для аматорів новин поєднують користувачів, які прагнуть генерувати цікавий контент у вигляді новин, коментарів та обговорень.

Соціальні мережі для аматорів кіно та музики спрямовані на об'єднання людей, які мають подібні інтереси в галузі мистецтва: кіно, музика, живопис, скульптура тощо. Завдяки спеціалізації вони мають набагато більше інформації про кіно, виставу чи про актора, який сподобався, i дають можливість відкривати дані одним кліком (натисканням на важіль маніпулятора - «мишки») та спілкуватися 3 однодумцями без участі сторонніх осіб [6].

Мобільні користувачі Інтернету складають одну з найдинамічніших груп на Інтернет-ринку, тому з' явилася низка соціальних мереж, призначених саме для мобільних користувачів. Ці мережі дають можливість ефективніше організовувати спілкування мобільних користувачів 3 урахуванням специфіки цієї групи. Зазначені соціальні мережі можуть бути не надто зручними для ділового спілкування, проте влаштовують осіб, які постійно перебувають у русі.

Незважаючи на певну кількість спільних рис, засоби Інтернеткомунікації, що належать до соціальних медіа, можуть значно різнитися за функціями та можливостями, які вони надають користувачам, а також принципами і нормами, що діють на «терені» кожного конкретного сайту.

Висновки та перспективи подальших досліджень. Як свідчить проведений аналіз, нові соціальні медіа та соціальні мережі поступово набувають ознак повноцінного соціального інституту сучасного суспільства. Їхніми головними перевагами є доступні інтерактивні комунікації, особиста 
участь користувачів у генерації та ретрансляції медійного контенту, високий ступінь залучення користувачів до процесу інтерактивної комунікації, максимальна швидкість зворотного зв'язку між користувачами, персоналізація користувачів тощо.

Соціальні мережі є складовою частиною соціальних медіа, оскільки всі вони вибудовують основні мережі Інтернет та ставлять за мету забезпечити комунікативні зв'язки користувачів. При цьому соціальні мережі мають власні, притаманні їм функції, які не завжди властиві класичному поняттю медіа.

Нині людство вступило до третьої епохи соціальних мереж. Після ейфорії «участі заради участі» сучасні мережі стають необхідним робочим інструментом для практичної діяльності, чи то військова справа, політика чи творчість. Зазначене потребує подальших наукових досліджень 3 метою впровадження інноваційних технологій, пов'язаних модернізацією освітнього процесу i, зокрема військової освіти [7, с. 295-307].

\section{ЛІТЕРАТУРА}

1. Білан Н. І. Соціальні комунікації в інформаційному суспільстві / Білан Н. І. // Наукові записки Інституту журналістики. - 2014. - Т. 56. - С. 171-175.

2. Демкович А. Нові соціальні медіа та соціальні мережі: взаємозв'язок та особливості / Анастасія Демкович // Наукові дослідження українського медійного контенту: соціальний вимір. - К. : Інститут журналістики КНУ ім. Тараса Шевченка. - № 2. - 2015. - 102 с. [Електронний ресурс] // Режим доступу: http://www.journ.univ.kiev.ua/ndumk/. - C. 12-18.

3. Гиллен П. Новые агенты влияния. USA / Пол Гиллен. - Society for New Communications Research, 2009. - 80 c.

4. Шестерёнкина Л. П. Основные характеристики новых социальных медиа / Л. П. Шестерёнкина, И. Д. Борченко. // Учёные записки ЗабГУ. Философия, история, востоковедение. - 2014. - № 2. - С. 107-111.

5. Половинчак Ю. Мобілізаційний та маніпулятивний потенціал дискурсу соціальних медіа в умовах перехідного суспільства [Електронний ресурс] / Половинчак Ю. // Нац. б-ка України ім. В. І. Вернадського. - Режим доступу : http://nbuviap.gov.ua/ index.php?option $=$ com_content $\&$ view $=$ article $\&$ id $=446$ : sotsialni-media\&catid $=8 \&$ Itemid $=350$. Назва $з$ екрану.

6. Готько О. Соціальні Інтернет-мережі та віртуалізація суспільного життя / О. Готько, О. Чайковська, Н. Наливайко. // Молодь і ринок. - 2016. - № 2. - С. 94-98.

7. Суспільно-комунікативні процеси у Збройних Силах України : підручник / [В. І. Алещенко, Т. В. Андрущенко, В. В. Стасюк та ін.] ; за заг. ред. В.С. Чорного. - К. : НУОУ ім. Івана Черняховського, 2017. - 372 с.

8. Бакулев Г. П. Массовая коммуникация. Западные теории и концепции : учеб. пособие для студентов вузов. - 2-е изд., перераб. и доп. / Геннадий Петрович Бакулев. М. : Аспект Пресс, 2010. - 192 с.

9. Чорна I. В. Дигіталізація як одна 3 тенденцій розвитку медіа галузі / Інна Віталіївна Чорна // Бібліотекознавство. Документознавство. Інформологія. - № 1. - 2014. C. $76-81$.

10. Чорний В. С. Військова організація України : становлення та перспективи розвитку: монографія / Чорний В. С. - Ніжин : ТОВ «Видавництво «Аспект-Поліграф», 2009. $-368 \mathrm{c}$. 


\section{REFERENCES}

1. Bilan, N.I. (2014). Sotsialni komunikatsii v informatsiinomu suspilstvi [Social communications in the information society]. Scientific notes of the Institute of Journalism, 56, 171-175. (in Ukrainian).

2. Demkovych, A. (2015). Novi sotsialni media ta sotsialni merezhi: vzaiemozv'iazok ta osoblyvosti [New social media and social networks: interconnection and features]. Scientific research of Ukrainian media content: social dimension, The Institute of Journalism of Taras Shevchenko National University of Kyiv, 12-18. Retrieved from http://www.journ.univ.kiev.ua/ndumk/. (in Ukrainian).

3. Gillen, P. (2009). Novyie agentyi vliyaniya. USA [New agents of influence. USA]. Society for New Communi-cations Research, 80. (in Russian).

4. Shesteryonkina, L. P. (2014). Osnovnyie harakteristiki novyih sotsialnyih media [The main characteristics of the new social media]. Scientific notes of Transbaikal State University. Philosophy, history, oriental studies, 2, 107-111. (in Russian).

5. Polovynchak, Y. Mobilizatsiinyi ta manipuliatyvnyi potentsial dyskursu sotsialnykh media $\mathrm{v}$ umovakh perekhidnoho suspilstva [Mobilization and manipulative potential of the social media discourse in a transitional society]. Retrieved from http://nbuviap.gov.ua/ index.php?option $=$ com_content $\&$ view $=$ article $\&$ id $=446$ : sotsialni-media $\&$ catid $=8 \&$ Itemid $=350$. (in Ukrainian).

6. Hotko, O. (2016). Sotsialni Internet-merezhi ta virtualizatsiia suspilnoho zhyttia [Social Internet Networks and Virtualization of Public Life] Youth and the market, 2, 94-98. (in Ukrainian).

7. Suspilno-komunikatyvni protsesy u Zbroinykh Sylakh Ukrainy: pidruchnyk [Socialcommunicative processes in the Armed Forces of Ukraine: a textbook]. (2017). NDU Ukraine named after Ivan Chernyahovskiy, DC Aleshchenko V. I., Andrushchenko T. V., Stasiuk V. V., under the general editorship of Chornyi V. S., 372. (in Ukrainian).

8. Bakulev, G. P. (2010). Massovaya kommunikatsiya. Zapadnyie teorii i kontseptsii : ucheb. posobie dlya studentov vuzov [Mass communication. Western theories and concepts: a textbook for university students (2nd ed.). Aspekt Press, 192. (in Russian).

9. Chorna, I. V. (2014). Dyhitalizatsiia yak odna z tendentsii rozvytku media haluzi [Digitization as one of the trends in the media industry]. Library Science. Documentation. Informology, 1, 76-81. (in Ukrainian).

10. Chornyi, V. S. (2009). Viiskova orhanizatsiia Ukrainy : stanovlennia ta perspektyvy rozvytku: monohrafiia [Military organization of Ukraine: formation and prospects of development: Monograph]. Nizhyn: Publishing House Aspekt-Polihraf, 368. (in Ukrainian).

\section{PEЗЮМЕ}

Виталий Чёрный,

доктор философских наук, профессор, Национальный университет обороны Украины имени Ивана Черняховского

\section{Новые социальные медиа и социальные сети в образовательном процессе}

Целью статьи является исследование сущности, генезиса и возможностей новых соииальных медиа и соичальных сетей в современном образовательном прочессе. Для этого использовались общенаучные и специальные методы исследования. В прочессе исследования выявлено, что образовательные социальные сети объединяют слушателей, курсантов, студентов и ориентированы на взаимодействие с иелью оказания помощии в реализачии академических проектов, проведения научных исследований или взаимодействия с научно-педагогчческими работниками. В статье было уточнено содержание отдельных понятий, получили дальнейшее развитие взгляды относительно 
их применения в образовательном процессе. Современная война и стремление Украины вступить в НАТО выдвигают новые требования $\kappa$ образовательному прочессу в Вооруженных Силах Украины. Всё это требует дальнейших научных исследований новых Интернет-технологий с иелью модернизации военного образования, приближение украинской армии к стандартам Североатлантического альянса.

Ключевые слова: новые сочиальные медиа; сочиальные сети; военное образование; коммуникативный процесс; Интернет; национальная безопасность; НАТО.

\section{SUMMARY}

Vitaliy Chornyi,

Doctor of Philosophy, Professor

National Defence University of Ukraine named after Ivan Chernyahovskyi

\section{New social media and social networks in the educational process}

Introduction. Modern interactive society is characterized by a constant increase and globalization of communications, the quantity and quality of which constantly grows.

Purpose. The purpose of the article is to study the essence, genesis and possibilities of new social media and social networks in the modern educational process.

Methods. To achieve this, general scientific and special research methods were applied. It was found that social media is both a technology and a kind of Internet sites.

Results. From a technological point of view, the social network is an interactive website with a large number of users whose content is filled by the participants themselves. Consequently, the main function of social networks is the association of people with similar interests in one community or group. It was found that educational social networks connect students and cadets. These services are focused on interaction in order to realize academic projects, research or connect scientific and pedagogical staff. Research social networks target the academic audience (researchers, doctoral students, adjuncts, graduate students). Such networks allow academic researchers to engage in collaborative research.

Originality. Therefore, the article clarifies the content of such concepts as «new social media», "social network» and develops the views on their application in the educational process.

Conclusion. Modern wars and Ukraine's aspirations for membership in NATO put forward new requirements for the educational process in the Armed Forces of Ukraine. These are teambased training using a variety of automated control systems, innovative forms of training, and, in particular, distance learning. This requires further research of Internet technologies, with an aim to modernize military education, bring the Ukrainian army closer to the North Atlantic Alliance standards.

Key words: new social media; social networks; military education; communicative process; Internet; national security; NATO. 